\title{
Bahan Ajar Berbasis Alqurun Teaching Model: Pemahaman Konsep Bangun Datar Siswa SMP
}

\author{
Astriana Putri ${ }^{1 \bowtie}$, Nanang Supriadi ${ }^{2}$, dan Rizki Wahyu Yunian Putra ${ }^{3}$ \\ ${ }^{1,2,3}$ Program Studi Pendidikan Matematika, Universitas Islam Negeri Raden Intan Lampung
}

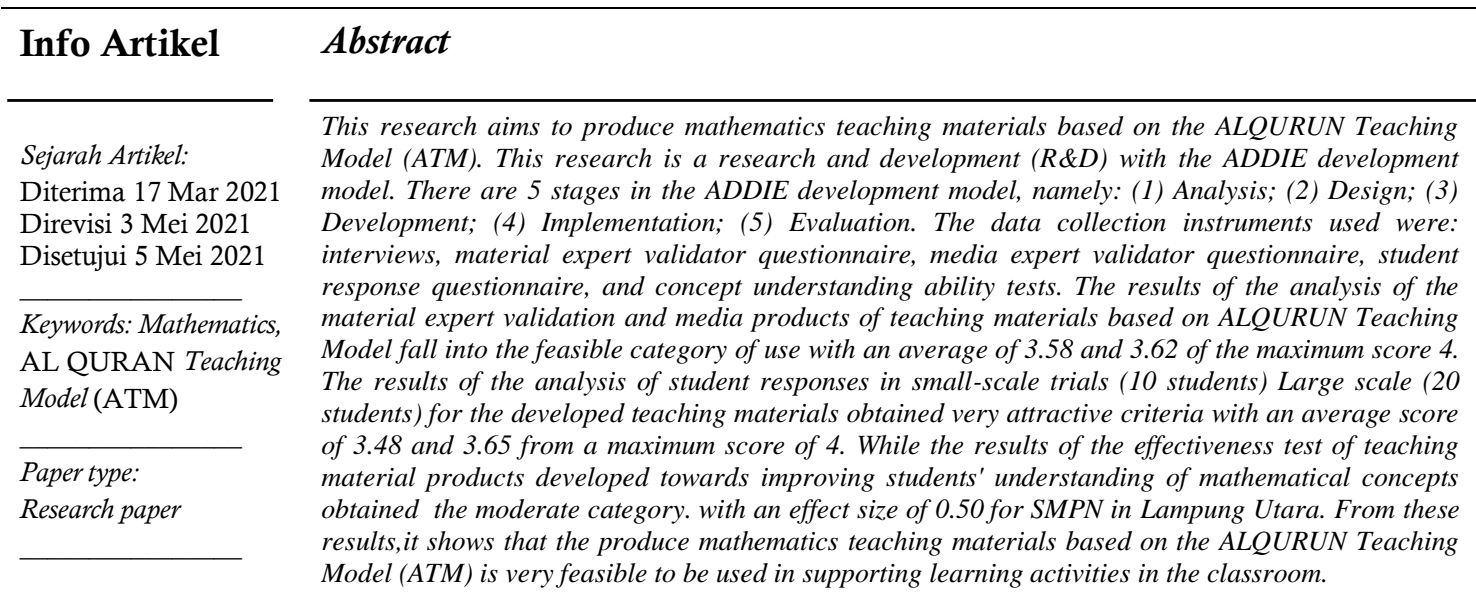

\begin{abstract}
Abstrak
Penelitian ini bertujuan menghasilkan bahan ajar matematika berbasis ALQURUN Teaching Model (ATM). Penelitian ini merupakan penelitian dan pengembangan (R\&D) dengan model pengembangan ADDIE. Terdapat 5 tahapan dalam model pengembangan ADDIE, yaitu: (1) Analysis; (2) Design; (3) Development; (4) Implementation; ( 5) Evaluation. Instrumen pengumpulan data yang digunakan yaitu: wawancara, angket validator ahli materi, angket validator ahli media, angket respons siswa dan tes kemampuan pemahaman konsep. Hasil analisis validasi ahli materi dan media produk bahan ajar berbasis ALQURUN Teaching Model masuk dalam kategori layak digunakan dengan rata-rata sebesar 3,58 dan 3,62 dari skor maksimal 4. Hasil analisis respons siswa pada uji coba skala kecil (10 siswa) dan skala besar (20 siswa) terhadap bahan ajar yang dikembangkan memperoleh kriteria sangat menarik rata-rata skor sebesar 3,48 dan 3,65 dari skor maksimal 4. Sementara hasil uji efektivitas produk bahan ajar yang dikembangkan terhadap peningkatan pemahaman konsep matematis siswa memperoleh kategori sedang dengan effect size sebesar 0,50 untuk siswa SMPN di Lampung Utara. Dari hasil tersebut, menunjukkan bahwa bahan ajar matematika berbasis ALQURUN Teaching Model (ATM) yang dikembangkan sangat layak untuk digunakan menunjang kegiatan pembelajaran dikelas.
\end{abstract}

(C) 2021 Universitas Muria Kudus

\begin{tabular}{lr}
\hline Alamat korespondensi: & p-ISSN 2615-4196 \\
Program Studi Pendidikan Matematika & e-ISSN 2615-4072 \\
Fakultas Keguruan dan Ilmu Pendidikan Universitas Muria Kudus & \\
Kampus UMK Gondangmanis, Bae Kudus Gd. L. It I PO. BOX 53 Kudus & \\
Tlp (0291) 438229 ex.147 Fax. (0291) 437198 & \\
E-mail: astrianaputri111@gmail.com &
\end{tabular}




\section{PENDAHULUAN}

Departemen Pendidikan Nasional (Depdiknas, 2007) menyatakan ada beberapa aspek yang perlu dikembangkan dalam pembelajaran matematika, diantaranya adalah pemahaman konsep, pemecahan masalah, serta penalaran dan komunikasi. Pentingnya penguasaan kemampuan-kemampuan tersebut sesuai dengan pendapat yang menyatakan dengan pemahaman konsep, siswa akan lebih mudah dalam memecahkan permasalahan karena siswa akan mampu mengaitkan serta memecahkan permasalahan tersebut dengan berbeka 1 konsep yang sudah dipahaminya. (Diana et al., 2020) menambahkan pemahaman konsep sebagai dasar untuk bernalar dan berkomunikasi sehingga dengan adanya pemahaman konsep siswa tidak hanya akan sekedar berkomunikasi tetapi siswa akan berkomunikasi secara baik dan benar.

Berbagai masalah banyak ditemukan dalam dunia pendidikan, salah satunya yaitu yang erat kaitannya dengan pembelajaran. Proses pembelajaran sendiri memilliki peranan terhadap kelangsungan pemahaman subjek didik dalam mencapai tujuan pembelajaran yang efektif dan efisien. Salah satu bidang yang kerap dipelajari dalam proses pembelajaran yaitu matematika. Hakikat matematika sebagai ilmu yang membahas masalah numerik, besaran dan kuantitas, sarana berfikir, struktur, kumpulan sistem dan alat (Hamzah Upu, Muhammad Darwis, 2015), tentu memerlukan sarana penunjang yang tepat. Namun pada kenyataannya proses pembelajaran matematika memiliki beberapa kesulitan yang diantaranya: (1) konsep yang diterangkan oleh pendidik di kelas tidak bisa dipahami oleh peserta didik, (2) peserta didik mengalami kesulitan dalam menangkap lambanglambang yang ada di sistem pembelajaran matematika, (3) kurang tertariknya minat belajar matematika yang diakibatkan oleh bahan ajar yang dipakai kurang menarik serta isi materinya pun terlalu padat.

Dalam upaya meningkatkan kemampuan pemahaman konsep, guru perlu mempersiapkan dan mengatur strategi penyampaian materi matematika kepada siswa. Strategi tersebut dapat berupa memilih bahan ajar yang dipadukan dengan model pembelajaran yang tepat di mana siswa dilibatkan secara aktif dalam proses pembelajaran sehingga dapat meningkatkan kemampuan pemahaman konsep pada siswa dan tercapainya hasil belajar siswa yang diharapkan.

Hasil analisis terhadap kesulitan siswa dalam mempelajari bangun datar, terindikasi bahwa siswa kurang menguasai konsep materi jajar genjang dan belah ketupat. Selain itu hasil wawancara terhadap siswa diperoleh informasi bahwa salah satu penyebab kurangnya pemahaman konsep dalam mata materi jajar genjang dan belah ketupat yaitu kurangnya bahan bacaan dalam mempersiapkan diri. Sementara belum ada bahan ajat yang praktis dari pendidik sebagai pegangan siswa dalam proses belajar. Bahan ajar yang dipakai hanya buku-buku yang ada diperpustakaan saja dan terbatas jumlahnya. Oleh sebab itu keterbatasan dari bahan bacaan mengakibatkan penguasaan konsep bangun datar rendah, agar siswa mendapat kemudahan dalam memahami berbagai konsep dalam proses belajar mengajar maka perlu disusun dan dikembangkannya suatu bahan ajar yang dapat mengarahkan dan merangsang proses berpikir siswa dalam memaksimalkan pemahaman konsep matematis siswa.

Bahan ajar yang baik harus dikembangkan berdasarkan pendekatan suatu pembelajaran maupun kemampuan yang akan dicapai (Rizki Wahyu Yunian, Rully Anggraini, 2003). Model pembelajaran yang cocok dan sesuai dengan karakteristik siswa SMP/MTs adalah ALQURUN Teaching Model (ATM). ATM dapat membantu siswa menguasai konsep untuk mencapai 4 kompetensi yang terdapat dalam kurikulum 2013 serta sekaligus menyesuaikan langkah pencapaian kognitif taksonomi bloom(Anggoro et al., 2021; Putra et al., 2020). Sebagaimana telah dikemukakan pembelajaran ALQURUN Teaching Model (ATM) mempunyai 7 tahapan yakni Acknowledge (Pengakuan), Literature (Penelusuran Pustaka), Quest (Menyelidiki), Unite (Menyatukan), Refine (Menyaring), Use (Penerapan), dan Name (Menamakan) (Putri, 2016).

Merujuk dari beberapa penelitian yang sudah dilakukan terkait dengan ALQURUN Teaching Model pada penelitian sebelumnya, memiliki hasil bahwa ALQURUN Teaching Model (ATM) dapat menumbuhkan motivasi dan aktivitas belajar siswa, dapat 
meningkatkan komunikasi matematis siswa (Sugeng, 2016), representatif matematis siswa (Soraya, 2019), serta pemecahan masalah matematis siswa (Suherman et al., 2019). Penelitian lain juga meneliti terkait kemampuan pemahaman konsep matematis yang dapat ditingkatkan dengan menerapkan model pembelajaran Search, Solve, Create and Share (SSCS) (Rafianti et al., 2020), discovery learning (Harisuddin, 2020), Kooperatif Tipe Student Teams Achievement Division (STAD) (Septian et al., 2020). Berdasarkan hasil penelitian terdahulu, sudah banyak sekali yang membahas tentang ALQURUN Teaching Model, namun belum ada yang menerapkannya untuk melihat peningkatan kemampuan pemahaman konsep matematis siswa baik secara parsial maupun secara simultan pada konsep bangun datar. Sehingga penulis melakukan penelitian berupa pengembangan bahan ajar berbasis ALQURUN Teaching Model (ATM) pada konsep bangun datar.

\section{METODE PENELITIAN}

Penelitian dilakukan pada semester ganjil tahun ajaran 2020/2021, dengan subjek uji coba 30 siswa pada kelas VII di SMPN Lampung Utara. Sedangkan objek dalam penelitian ini adalah bahan ajar berbasis ALQURUN Teaching Model (ATM) pada materi jajar genjang dan belah ketupat.

Produk yang didapatkan pada penelitian ini merupakan produk bahan ajar berbasis ALQURUN Teaching Model pada materi jajar genjang dan belah ketupat untuk siswa SMP/MTs. Penelitian pengembangan ini menggunakan model pengembangan ADDIE. Pemilihan model ini didasari atas pertimbangan model ini mudah dipahami, selain itu juga model ini dikembangkan secara sistematis dan berpijak pada landasan teoritis desain pembelajaran yang dikembangkan. Model ini disusun secara terprogram dengan kegiatan sistematis dalam upaya pemecahan masalah belajar yang berkaitan dengan media belajar yang sesuai dengan kebutuhan dan karakteristik siswa. Pada model penelitian ADDIE terdiri dari 5 fase yakni: Analysis, Design, Development, Implementation, dan Evaluation.

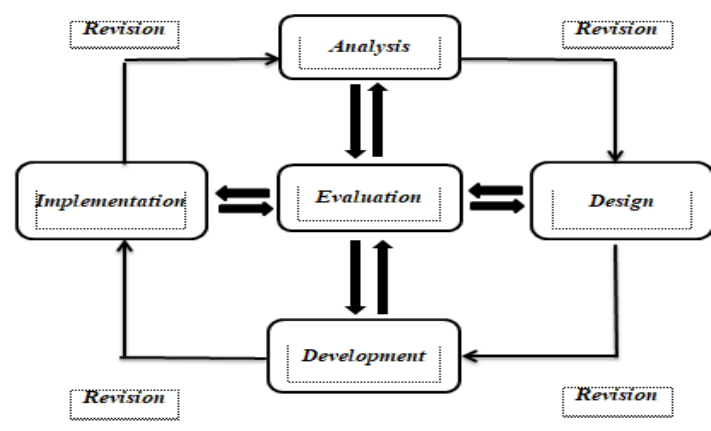

\section{Gambar 1. Tahapan Model ADDIE}

Pada implementasi penelitian. dan pengembangan (Research and Development) data yang digunakan peneliti terdapat 2 macam data yang dihimpun, yakni: (1) data kualitatif, berbentuk nilai jenis pembelajaran memakai bahaan ajar berbasis ALQURUN Teaching Model sesuai dengan angket yang telah diisi oleh ahli materi dan siswa; (2) Data Kuantitatif berbentuk skor penelitian tiap nilai standar penilaian pada angket validasi bahan ajar pada materi operasi aljabar yang diisi oleh ahli materi, ahli media serta guru matematika SMP, dan siswa sebagai pemakai bahan ajar. Selanjutnya Penilaian tersebut diubah menjadi skor dengan skala likert.

Penelitian ini menggunakan teknik analisis data yaitu deskriptif kuantitatif. Data yang didapat dari instrumen uji. coba akan ditelaah memakai statistik deskriptif. Tujuan analisis ini adalah agar memberikan gambaran karakter data pada tiap-tiap variabel. Penilaian rata-rata perhitungan tersebut didapat menggunakan rumus di bawah ini:

Dengan :

$$
\bar{x}=\frac{\sum_{i=1}^{n} x_{1}}{n}
$$

Keterangan :

$$
x_{i}=\frac{\text { jumlah.skor }}{\text { skor maksimal }} \times 4
$$

$\bar{x}=$ rata-rata akhir

$x_{i}=$ nilai uji operasional. angket tiap peserta

didik

$n=$ jumlah peserta didik

\section{Analisis Data Validasi Ahli}

Angket. validasi ahli mengenai aspek penyampaian, keteraturan isi, kebahasaan dan keteraturan bahan ajar yang mempunyai 4 alternatif jawaban yang cocok dengan isi pertanyaan. Skor penilaian dari setiap opsi jawaban adalah sangat baik, baik, kurang baik, sangat kurang baik.

Hasil skor penilaian pada tiap validator ahli media serta ahli materi selanjutnya dihitung 
Astriana Putri, Nanang Supriadi, dan Rizki Wahyu Yunian Putra

Anargya: Jurnal Pendidikan Matematika, Vol. 4 No.1, April 2021 https://dx.doi.org/10.24176/anargya.v4i1.6028

rata-rata serta dikonversi ke pernyataan guna mengetahui tingkat kelayakan dan validasi bahan ajar berbasis ALQURUN. Pengkonversian skor menjadi pernyataan penilaian terlihat pada Tabel 1 berikut:

Tabel 1. Kriteria Kelayakan

\begin{tabular}{|c|c|c|}
\hline Skor Kualitas & $\begin{array}{l}\text { Kriteria } \\
\text { Kelayakan }\end{array}$ & Keterangan \\
\hline $\begin{array}{l}3,26<\bar{x} \\
\leq 4,00\end{array}$ & Layak & Tidak Revisi \\
\hline $\begin{array}{l}2,51<\bar{x} \\
\leq 3,26\end{array}$ & Cukup Layak & $\begin{array}{l}\text { Revisi } \\
\text { Sebagian }\end{array}$ \\
\hline $\begin{array}{l}1,76<\bar{x} \\
\leq 2,51\end{array}$ & Kurang Layak & $\begin{array}{l}\text { Revisi } \\
\text { Sebagian }\end{array}$ \\
\hline $\begin{array}{l}1,00<\bar{x} \\
\leq 1,76\end{array}$ & Tidak Layak & Revisi Total \\
\hline
\end{tabular}

\section{Analisis Data Uji Coba Produk}

Angket respons siswa dengan pemakaian produk bahan ajar mempunyai 4 alternatif jawaban yang setara dengan informasi pada pertanyaan. Tiap-tiap jawaban mempunyai nilai yang berlainan yang berarti taraf kecocokan produk bagi pemakai bahan ajar. Skor penilaian pada setiap opsi jawaban yaitu sangat setuju , setuju, tidak setuju, sangat tidak setuju (Wahyu et al., 2017)

Skor hasil penilaian tiap-tiap peserta didik kemudian dicari rata-rata dan dikonversi ke pernyataan agar selanjutnya dapat mengetahui kemenarikannya. bahan ajar elektronik berbasis ALQURUN Teaching Model Pengkonversian skor terdapat pada Tabel 2 di bawah ini:

Tabel 2. Kriteria kemenarikan

\begin{tabular}{cc}
\hline Skor Kualitas & Kriteria Kemenarikan \\
\hline $3,26<x \leq 4,00$ & Sangat. Menarik \\
\hline $2,51<x \leq 3,26$ & Menarik. \\
\hline $1,76<x \leq 2,51$ & Kurang Menarik. \\
\hline $1,00<x \leq 1,76$ & Tidak Menarik \\
\hline
\end{tabular}

\section{Analisis Data Uji Efektivitas}

Uji efektivitas pada penelitian ini dilakukan dengan memberikan pretest dan postest kepada siswa. Hasil pretest dan postest tersebut akan dihitung menggunakan rumus effect size sebagai berikut:

Keterangan:

$$
d=\frac{\left(M_{2}-M_{1}\right)}{S D_{\text {Polled }}}
$$

$d=$ effect size

$M_{1}=$ rata-rata pretest

$M_{2}=$ rata-rata postes

$S D_{\text {Polled }}=$ standar deviasi pooled

dengan kategori effect size sebagai berikut.

Tabel 3. Kategori Effect Size

\begin{tabular}{cc}
\hline Effect Size & Kategori \\
\hline$d \leq 0,4$ & Rendah \\
\hline
\end{tabular}

\begin{tabular}{cc}
\hline Effect Size & Kategori \\
\hline $0,4<d<0,8$ & Sedang \\
\hline$d \geq 0,8$ & Tinggi \\
\hline
\end{tabular}

\section{HASIL DAN PEMBAHASAN}

Pengembangan bahan ajar berbasis ALQURUN Teaching Model pada materi operasi aljabar dengan langkah ADDIE dibagi menjadi 5 tahapan yaitu:

\section{Tahap Analysis}

Pada penelitian fase analisis meliputi telaah kurikulum dan telaah karakter siswa. Sesuai dengan observasi terhadap siswa pada proses pembelajaran, peneliti memberi kesimpulan bahwa beberapa karakter siswa pada pembelajaran matematika adalah sebagai berikut: (1) Siswa kurang aktif dalam pembelajaran; (2) Siswa masih mengandalkan teman sebangku untuk melihat hasil penyelesaian masalah yang diberikan; (3) Bahan ajar yang digunakan dalam kelas hanya buku paket yang ditetapkan oleh sekolah serta LKS yang sederhana sehingga siswa kurang berkembang dalam menyelesaikan soal dalam bentuk pemecahan masalah. Setelah melakukan analisis, peneliti melakukan evaluasi. Evaluasi yang diperoleh yaitu siswa memerlukan bahan ajar yang beragam selain buku paket dan LKS agar siswa lebih aktif dan dapat meningkatkan kemampuan pemahaman konsep matematis siswa. Oleh karenanya jika pada penelitian sebelumnya mengembangkan suatu bahan ajar berbentuk LKPD atau LKS pada penelitian kali ini peneliti mengembangkan suatu bahan ajar berbentuk modul berbasis ALQURUN Teaching Model untuk meningkatkan kemampuan pemahaman konsep matematis siswa pada konsep bangun datar.

\section{Tahap Design}

Peneliti menyiapkan penyusunan rancangan bahan ajar, pemilihan penataan materi, serta susunan draft bahan ajar. Pada tahapan ini peneliti melakukan desain produk, yaitu: desain Cover, kata pengantar, daftar isi, petunjuk penggunaan bahan ajar, tampilan isi materi, latihan, daftar pustaka dan daftar riwayat penulis. Berikut ini adalah beberapa tampilan dari bahan ajar yang telah peneliti dikembangkan.

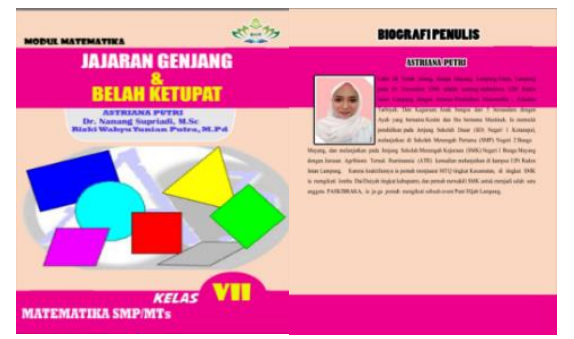

Gambar 2. Cover Depan dan Belakang 


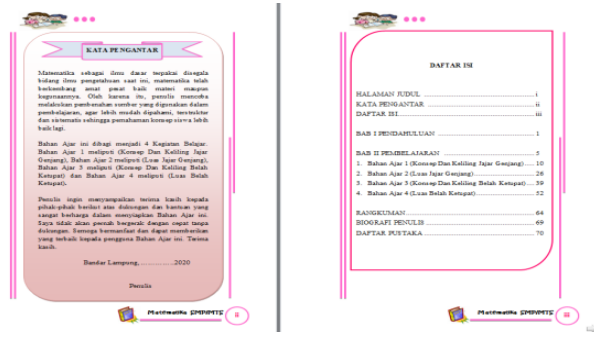

Gambar 3. Kata Pengantar dan Daftar Isi

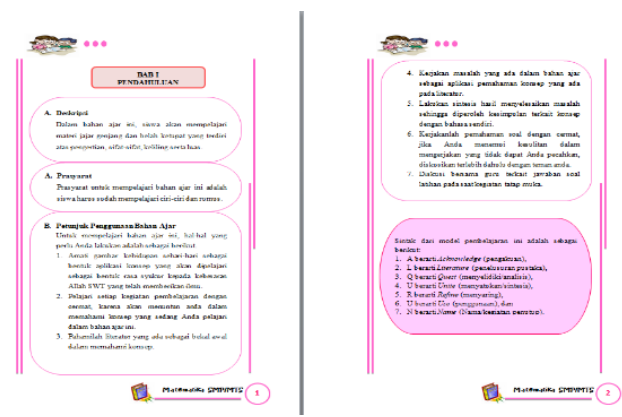

Gambar 4. Petunjuk Penggunaan

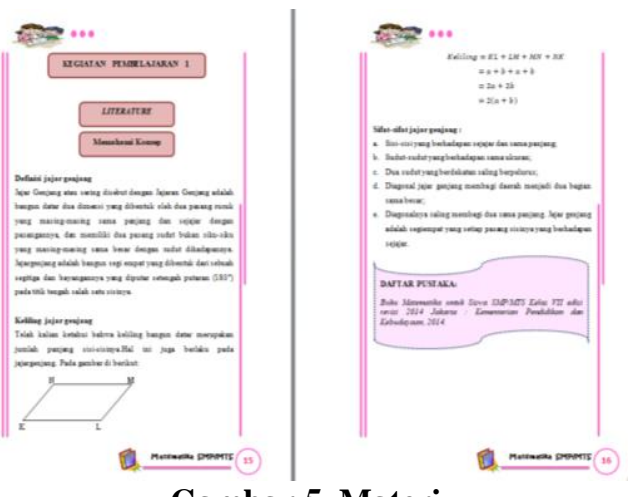

Gambar 5. Materi

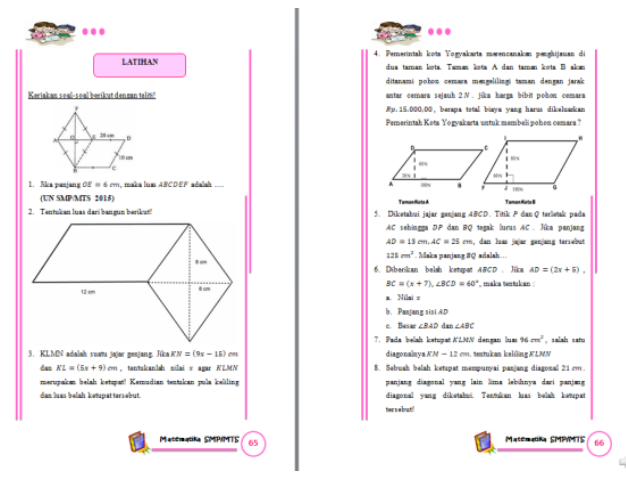

Gambar 6. Latihan

Tahap Development

Hasil pengembangan yang dilaksanakan peneliti menciptakan produk yakni bahan ajar berbentuk modul berbasis ALQURUN Teaching model.

a. Hasil Validasi Ahli Materi
Validasi ahli materi bertujuan untuk melihat kualitas kelayakan serta kesamaan materi pengembangan bahan ajar. Validator ahli materi yakni 2 dosen matematika UIN Raden Intan Lampung (validator I dan II) dan 1 guru matematika (validator III). Berikut ini hasil validasi ahli materi.

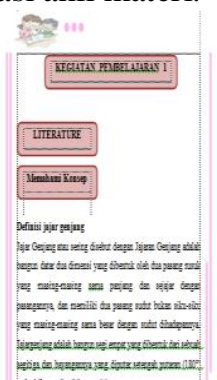

Sebelum Direvisi

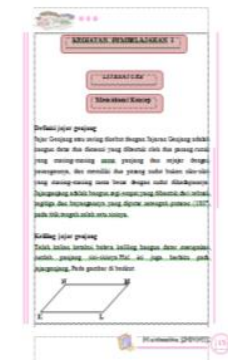

Sesudah Direvisi

\section{Gambar 7. Tampilan Materi Sebelum dan} Sesudah Direvisi

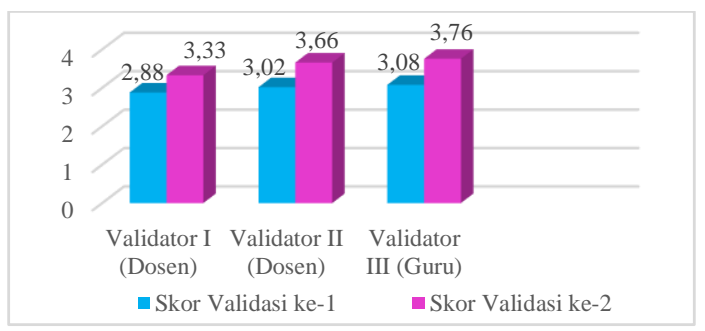

\section{Gambar 8. Grafik Hasil Validasi Ahli}

Gambar 8 menunjukkan hasil validasi ahli materi tahap 1 dan 2. Berdasarkan grafik tersebut terlihat bahwa hasil validasi ahli materi tahap 1 memperoleh rata-rata 2,99 dengan kriteria "Cukup Layak" dan harus melakukan revisi sebagian. Pada validasi tahap I ini bahan ajar yang dikembangkan belum memperoleh kriteria layak untuk digunakan, karena terdapat beberapa bagian dari bahan ajar yang masih kurang sempurna dan harus diperbaiki serta disempurnakan. Setalah melakukan revisi dan perbaikan akhirnya pada validasi tahap 2 memperoleh rata-rata 3,58 dan memperoleh kriteria "Layak" sebagai sebuah bahan ajar.

b. Hasil Validasi Ahli Media

Tujuan validasi ahli media adalah agar mengenali kriteria optimal yang digunakan pada penyusunan bahan ajar. Validator ahli media adalah 2 dosen matematika UIN Raden Intan Lampung (validator I dan II) dan 1 guru matematika (validator III). Berikut ini merupakan hasil validasi ahli media. 


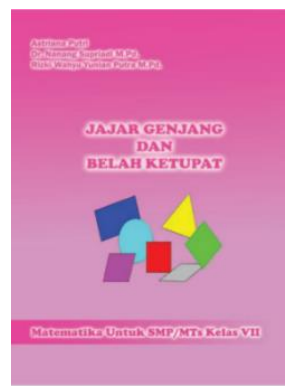

Sebelum direvisi

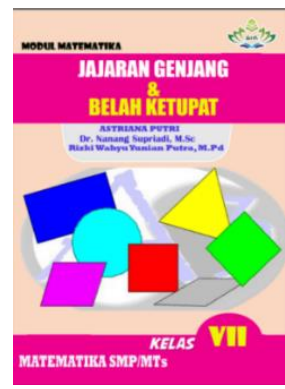

Setelah di revisi

Gambar 9. Tampilan Cover Sebelum dan Sesudah Direvisi

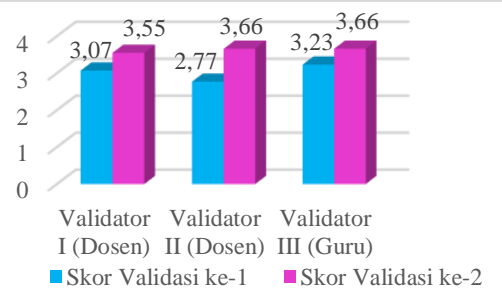

\section{Gambar 10. Grafik Hasil Validasi Ahli} Media

Gambar 10 di atas menunjukkan hasil validasi ahli media tahap 1 dan 2 . Berdasarkan grafik tersebut terlihat bahwa hasil validasi ahli media tahap 1 diperoleh rata-rata 3,02 dengan kriteria "Cukup Layak" dan harus melakukan revisi sebagian. Pada validasi tahap I ini bahan ajar yang peneliti kembangkan belum memperoleh kriteria layak untuk digunakan, karena terdapat beberapa bagian dari bahan ajar yang masih kurang sempurna dan harus diperbaiki serta disempurnakan. Setelah melakukan revisi dan perbaikan maka hasil validasi tahap 2 diperoleh rata-rata 3,62 dan memperoleh kriteria "Layak" sebagai sebuah bahan ajar.

c. Uji Respons Kemenarikan

Uji respons kemenarikan dilakukan guna mengetahui tingkat kemenarikan produk bahan ajar berbasis ALQURUN Teaching Model yang telah dibuat. Uji respons kemenarikan dilakukan dengan dua tahap yaitu uji coba skala kecil dan uji coba skala besar. Uji coba skala kecil dilaksanakan oleh 10 orang peserta didik dengan tingkat kemampuan heterogen. Sedangkan uji coba skala besar dilakukan oleh 20 orang peserta didik dengan tingkat kemampuan heterogen. Uji coba respons kemenarikan ini dilaksanakan pada dua sekolah yaitu SMPN di Lampung Utara. Berikut ini merupakan hasil uji respons kemenarikan bahan ajar berbasis ALQURUN Teaching Model.

Berdasarkan hasil uji kelas kecil dari 30 peserta didik disimpulkan bahwa bahan ajar (modul) berbasis ALQURUN Teaching Model

(ATM) layak digunakan dengan rata-rata nilai akhir adalah 3,48 yang mempunyai kategori "sangat menarik". Hasil penilaian skala besar didapat nilai rata-rata sebesar 3,65 dengan kriteria "sangat menarik", hal ini memperlihatkan bahwa bahan ajar berbasis ALQURUN Teaching Model yang dikembangkan oleh peneliti memiliki kriteria menarik sebagai media pembelajaran yang akan digunakan pada materi jajar genjang dan belah ketupat. Skor rata-rata uji skala kecil dan uji skala besar masing-masing sebesar 3,48 dan 3,65 di mana perolehan skor memiliki peningkatan. Berikut grafik perbandingan uji skala kecil dan skala besar.

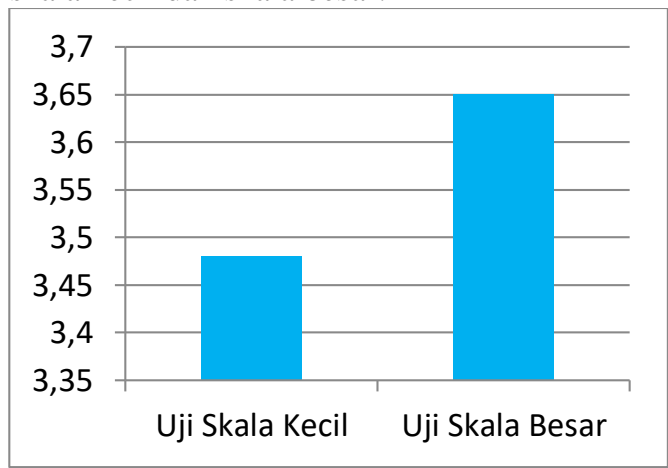

Gambar 11. Grafik Hasil Uji Coba

Kemenarikan SMPN di Lampung Utara

Gambar 11 di atas menunjukkan grafik hasil uji respons kemenarikan produk bahan ajar berbasis ALQURUN Teaching Model. Berdasarkan grafik tersebut terlihat bahwa hasil uji coba skala kecil memperoleh nilai rata-rata 3,48 dengan kriteria sangat menarik. Sedangkan hasil uji coba skala besar memperoleh nilai ratarata 3,65 dengan kriteria sangat menarik.

\section{Tahap Implementation}

Pada tahap implementation peneliti menggunakan bahan ajar berbasis ALQURUN Teaching Model yang telah divalidasi. tahap implementasi penggunaan bahan ajar ini dilakukan pada kelas VII SMPN di Lampung Utara. pada tahap ini peneliti memberikan pretest dan posttes kepada siswa, kemudian akan dihitung tingkat keefektivitasannya. Berikut ini merupakan hasil uji efektivitas produk bahan ajar berbasis ALQURUN Teaching Model:

Tabel 4. Hasil Uji Efektivitas siswa SMPN di Lampung Utara

\begin{tabular}{ccccc}
\hline \multicolumn{6}{c}{ Lampung Utara } \\
& & $\begin{array}{c}\text { Pre- } \\
\text { Test }\end{array}$ & $\begin{array}{c}\text { Post- } \\
\text { Test }\end{array}$ & D \\
\hline 30 & Rata-rata & 52,90 & 72,26 & 0,50 \\
sis & Standar & 53,31 & 11,71 & \\
wa & Deviasi & & & \\
\hline & Kategori & & Sedang & \\
\hline
\end{tabular}


Berdasarkan tabel 4 di atas, terlihat hasil pretest dan posttest SMPN di Lampung Utara. Hasil pretest siswa memperoleh nilai rata-rata 52,90 dengan standar deviasi sebesar 53,31; sedangkan hasil posttest memperoleh nilai ratarata 72,26 dengan standar deviasi sebesar 11,71. Berdasarkan hasil pretest dan postes tersebut, terlihat peningkatan pemahaman konsep siswa pada materi jajar genjang dan belah ketupat setelah menggunakan bahan ajar yang dibuat. Setelah dilakukan uji efect size diperoleh skor peningkatan pemahaman konsep matematis siswa, yaitu nilai $d$ sebesar 0,50 dengan kategori peningkatan "Sedang". Berdasarkan hasil uji efect size kedua sekolah di atas, diperoleh kesimpulan bahwa bahan ajar berbasis ATM efektif untuk meningkatkan pemahaman konsep matematis siswa pada materi jajar genjang dan belah ketupat.

\section{Tahap Evaluation}

Pada tahap ini peneliti melakukan analisis data yang didapat, yaitu telaah validasi bahan ajar oleh para ahli serta analisis uji respons kemenarikan bahan ajar oleh siswa. Hasil evaluasi yang diperoleh yaitu siswa memerlukan bahan ajar yang beragam selain buku paket dan LKS agar siswa lebih aktif dan dapat meningkatkan kemampuan pemahaman konsep matematis siswa. Hasil validasi ahli materi dan ahli media diperoleh skor sebesar 3,58 dan 3,62 dengan kategori layak. Hasil uji respons siswa kelompok kecil dan besar diperoleh hasil 3,48 dan 3,65 dengan kategori sangat menarik. Sementara hasil uji efektivitas diperoleh hasil $d$ sebesar 0,50 dengan kategori sedang.

\section{SIMPULAN}

Berdasarkan hasil dari proses penelitian pengembangan (Research and Development), maka didapat kesimpulan bahwa bahan ajar matematika berbasis ALQURUN Teaching Model dinyatakan valid dan layak sebagai sebuah bahan ajar yang dapat menunjang proses pembelajaran dari peserta didik dengan memenuhi kriteria kevalidan media mencapai skor validasi sebesar 3,62. Bahan ajar yang dikembangkan juga telah mendapatkan respons menarik dari peserta didik dengan diperoleh hasil 3,48 dan 3,65 dengan kategori sangat menarik. Sementara hasil uji efektivitas pada peserta didik kelas VII SMPN di Lampung Utara menyatakan bahwa terbukti pemahaman konsep peserta didik pada materi jajar genjang dan belah ketupat diperoleh hasil $d$ sebesar 0,50 dengan kategori sedang.

Secara umum, penggunaan bahan ajar berbentuk modul berbasis ALQURUN
Teaching Model (ATM) memberikan pengaruh yang sangat baik bagi peserta didik. Peserta didik menjadi lebih antusias dalam belajar, memiliki kepercayaan diri yang tinggi dan kemandirian dalam belajar, dapat lebih termotivitasi dalam menyelesaikan permasalahan yang dihadapinya dalam proses belajar mengajar serta dapat mengembangkan kreativitas belajarnya.

Berdasarkan hasil dari proses penelitian pengembangan (Research and Development). Maka disaran bahwa bahan ajar yang hanya menyajikan materi jajar genjang dan belah ketupat sehingga diharapkan dapat dilakukan pengembangan pada materi lain. Bahan ajar ini hanya dibuat dalam bentuk cetak, sehingga diharapkan perlu diperbaharui untuk mengikuti perkembangan zaman misal dalam bentuk elektronik. Peneliti berharap dapat melanjutkan atau menerapkan bahan ajar yang dikembangkan pada subjek atau sampel berbeda untuk memperbaiki kekurangan bahan ajar yang dikembangkan agar lebih menarik dan efektif.

\section{DAFTAR PUSTAKA}

Anggoro, B. S., Wahyu, R., \& Putra, Y. 2021. Pengembangan Bahan Ajar Elektronik Bilangan Bulat Dan Pecahan Berbasis ALQURUN Teaching Model. Jurnal Pendidikan Matematika (AL KHAWARIZMI), 1(2), 50-59.

Depdiknas. 2007. Kajian Kebijakan Kurikulum Mata Pelajaran Matematika. Pusat Kurikulum Balitbang Depdiknas.

Diana, P., Marethi, I., \& Pamungkas, A. S. 2020. Kemampuan Pemahaman Konsep Matematis Siswa: Ditinjau Dari Kategori Kecemasan Matematik. SJME (Supremum Journal of Mathematics Education), 4(1), 24-32.

Hamzah Upu, Muhammad Darwis, J. 2015. Efektivitas Penerapan Model Berbasis Masalah Setting Kooperatif Dengan Pendekatan Saintifik Dalam pembelajaran Matematika Di Kelas X SMA Negeri 11 Makasar. Jurnal Daya Matematis, 3(1), 345.

Harisuddin, M. I. 2020. Penerapan Discovery Learning Untuk Meningkatkan Kemampuan Pemahaman Konsep Matematis Siswa Smpn 1 Pagaden. Jurnal Mitra Pendidikan, 4(2), 52-61.

Putra, R. W. Y., Suherman, S., Anggoro, B. S., \& Pamungkas, A. S. 2020. Alqurun Teaching Model-Based Trigonometry Teaching 
Astriana Putri, Nanang Supriadi, dan Rizki Wahyu Yunian Putra

Anargya: Jurnal Pendidikan Matematika, Vol. 4 No.1, April 2021 https://dx.doi.org/10.24176/anargya.v4i1.6028

Material. Indonesian Journal of Science and Mathematics Education, 3(2), 219227.

Putri, Y. B. 2016. Pengembangan Bahan Ajar Berbasis ALQURUN Teaching Model (ATM) Pada Materi Teorema Phytagoras. Universitas Lampung.

Rafianti, I., Iskandar, K., \& Haniyah, L. 2020. Pembelajaran Search, Solve, Create and Share (SSCS) untuk Meningkatkan Pemahaman Konsep dan Disposisi Matematis Siswa. Journal of Medives: Journal of Mathematics Education IKIP Veteran Semarang, 4(1), 97.

Ridwan. 2003. Skala Pengukuran VariabelVariabel Penelitian. Afabetha.

Rizki Wahyu Yunian, Rully Anggraini, P. 2003. Pengembangan Bahan Ajar Materi Trigonometri Berbantuan Software Imindmap Pada Peserta Didik Di SMA. 1, 42.

Septian, A., Agustina, D., \& Maghfirah, D. 2020. Model Pembelajaran Kooperatif Tipe Student Teams Achievement Division
(STAD) untuk Meningkatkan Pemahaman Konsep Matematika. Mathema Journal, 2(2), 10-22.

Soraya, R. 2019. Pengembangan Bahan Ajar Berbasis ALQURUN Teaching Model (ATM) untuk Meningkatkan Representatif Matematis Siswa. Universitas Lampung.

Sugeng, S. 2016. Model Pembelajaran AL QURUN (AlQurun Teaching Model/ATM), Proceeding Mathematics, Science, and Education National Confernce (MSENCo).

Suherman, S., Suharno, A. S., \& Istihana, I. 2019. ALQURAN Teaching Model: The Effect Of Problem Solving Ability and Gender On Mathematics. HUMANISMA : Journal of Gender Studies, 3(01), 25.

Wahyu, R., Putra, Y., Putra, F. G., \& Putra, N. W. 2017. Pengembangan Desain Didaktis Bahan Ajar Materi Pemfaktoran Bentuk Aljabar pada Pembelajaran Matematika SMP. 1(2), 97-102. 